\title{
Dependent Yet Defiant: The Implications of Unilateralism in Iraqi Kurdistan
}

\author{
Sebastian Klich
}

\section{Abstract}

Since 2009 the Kurdistan Regional Government (KRG), which is recognised in Iraq's 2005 constitution as the governing body of the Kurdistan Region of Iraq, has repeatedly signed oil exploration contracts with international oil companies (IOCs) that the Iraqi federal government considers unconstitutional. In light of its ethno-nationalist heritage, the KRG's unilateral actions have widely been perceived as part of a broader strategy to gain juridical independence. This essay examines the implications of the KRG's provocative behaviour and assesses the contention that the KRG is driven by underlying motivations to establish an independent state. It is also demonstrated here that interpreting KRG unilateralism as a move towards secession is simplistic; the KRG is economically reliant on Baghdad and, although Turkey has recently fostered closer relations with the Iraqi Kurds, its historical opposition to an independent Kurdish state will continue. Rather, it is argued that the KRG signing contracts with IOCs is a strategic manoeuvre designed to maximise the economic autonomy of the Kurdistan region in the context of an increasingly fragmented Iraq.

\section{Introduction}

In 2005 the status of the Kurdish Regional Government (KRG) was officially recognised in the Iraqi constitution, enshrining the right of the Iraqi Kurds to localised power over 'all administrative requirements of the region'. ${ }^{1}$ Within the constitution an important distinction was made between the right to manage existing and future oil fields, the former falling to the federal government and the latter to the regions. ${ }^{2}$ Or so it seemed. Contrasting views and interpretations

1 Liam Anderson, 'Internationalizing Iraq's Constitutional Dilemma', in The Kurdish Policy Imperative, eds Robert Lowe and Gareth Stansfield (London: Royal Institute of International Affairs, 2010) 150.

2 ibid. 
have been contested by constitutional experts worldwide, debating who can legally manage what, according to the constitution, and a clear consensus is yet to emerge. ${ }^{3}$ Baghdad insists that all contracts for oil exploration and production must be developed in partnership with the central government. The KRG refutes this position with its actions and, since 2009, it has signed over 50 contracts with international oil companies (IOCs), contracts that Baghdad considers to be illegal. Given the majority of the KRG's income streams directly from the Iraqi national budget, this aggressive economic behaviour, which is defiant of Baghdad, has stimulated a whirlwind of suppositions through commentary and media worldwide speculating that the time of an independent Kurdistan is drawing near. ${ }^{4}$

In analysing the implications of such provocative behaviour, this essay will firstly consider the contention that the KRG is strategically positioning itself for the creation of an independent Kurdish state, reinforcing the historical trajectory of Kurdish nationalistic aspirations, alongside the KRG-directed cultural change and economic growth that has recently taken place. ${ }^{5}$ The essay then examines the consequences of the KRG's oil-sector management in the broader domestic context of Iraq. The KRG's domestic political motivations outside of the independence debate are examined by highlighting the relationships of multifaceted tensions that exist between Erbil (capital of the KRG) and Baghdad, the widening of sectarian rifts, and the attempted secession of other Iraqi provinces. Next, neighbourly cooperation with Turkey is scrutinised by assessing the motivations that underpin this purposeful collaboration of regional convenience, and shining a revealing light on the implications it has for Kurdish independence.

After outlining the sturdy barriers to a separate Kurdish state being established, the essay finally draws the analysis together to argue that the current obstacles to achieving independence are too great for this to be the intent of the Iraqi

\footnotetext{
3 Peter D Cameron, 'Contracts and Constitutions: The Kurdish Factor in the Development of Oil in Iraq', International Journal of Contemporary Iraqi Studies 5:1 (2011) 85.

4 See Gareth Stansfield, 'The Unraveling of the Post-First World War State System? The Kurdistan Region of Iraq and the Transformation of the Middle East', International Affairs 89:2 (2013); The Economist, 'Northern Iraq: Peace, Harmony and Oil', http://www.economist.com/news/middle-east-and-africa/21576394-despiteassertions-contrary-iraqs-kurds-are-inching-towards-outright (20 April 2013) access 21 April 2013; Ibrahim Malazada, 'Now is the Time for an Independent Kurdistan', Asharq Al-Awsat http://www.aawsat.net/2013/04/ article55298106(8 April 2013) accessed 9 April 2013; Ed Blanche, 'Kurds: Attaining the Impossible Dream?', The Middle East 440:1 (February 2013) 13.

5 This essay uses the terms 'Iraqi Kurdistan' and 'The Kurdistan Region of Iraq' interchangeably, referring in both instances to the region controlled by the KRG. The title of 'The Republic of Kurdistan' refers to the hypothetical state that would likely be established if the Kurdistan Region of Iraq were to attain independent statehood and no longer exist as a federal region. The 'central government' refers to the Iraqi government in Baghdad.
} 
Kurds, and considers that the KRG signing contracts with IOCs is a strategic ploy for maximising Kurdish economic autonomy in the context of an increasingly fractured Iraq. ${ }^{6}$

\section{The Republic of Kurdistan?}

Speculation on the prospect that the KRG is seeking to establish an independent state has been influenced by the vitality and virility of the Kurdish national movement. The Kurds like to think the "earthly paradise ${ }^{7}$ that exists in the north of Iraq today is the cumulative result of a century of struggle and hardship. The Kurds were the primary beneficiaries of the 2003 Iraq War. The perceived benefits came, however, at a high price. ${ }^{8}$ A full historical account of the struggle of the Kurds is beyond the scope of this essay, but the following points are key to appreciating the strong and resilient sense of Kurdish nationalism.

The Kurdish people can be traced as an identifiable ethnic group for more than 2000 years, though it was at the turn of the twentieth century that they established a sense of national community. ${ }^{9}$ The end of the Ottoman Empire and World War I held out the promise of Kurdish independence in the ill-fated 1920 Treaty of Sevres. ${ }^{10}$ Rejection by Turkey and continuing war led to the 1923 Treaty of Lausanne, a political compromise that pacified Turkey, but sacrificed a Kurdish state. ${ }^{11}$ After Iraq gained its independence in October 1932, ${ }^{12}$ Sheikh Ahmed Barzani led the first (failed) uprising demanding Kurdish autonomy. ${ }^{13}$ In 1946 the Kurdish Democratic Party (KDP) was established, announcing the independent Mahabad Republic of the Kurds, which lasted until 1947 when Iran's forces invaded. ${ }^{14}$

The 1970 peace accord was the first recognition of basic Kurdish autonomy by the Iraqi government. ${ }^{15}$ The period 1988-91 saw Saddam Hussein's genocidal 'Anfal' campaign attempt the extermination of the Kurds and resulted in the killing of between 50,000 and 100,000 people. ${ }^{16}$ In 1992 the first elections of the Kurdistan region were held, and the KRG was established. Since the KRG's

\footnotetext{
6 The focus of this essay is the implications of KRG unilateralism. As such, an examination of the Kurdish nationalist movements in neighboring countries is beyond its scope.

7 The Economist, 'Northern Iraq'.

8 Denise Natali, 'The Spoils of Peace in Iraqi Kurdistan', Third World Quarterly 28:6 (August 2007) 1111.

9 David McDowall, A Modern History of the Kurds (New York: St Martin's Press, 2004) 2.

10 Wadie Jwaideh, The Kurdish National Movement: Its Origins and Development (Syracuse University Press, 2006) 130-31.

11 ibid., 132.

12 Gareth Stansfield, Iraq (Cambridge: Polity, 2007) 49.

13 McDowall, A Modern History of the Kurds, 179.

14 ibid., 296-97.

15 ibid., 327-28.

16 ibid., 359.
} 
formation, a territorially based nationalism has developed in Iraqi Kurdistan, which takes precedence over the ethnically oriented form, distinguishing the Iraqi-Kurd movement from its regional ethnic counterparts. ${ }^{17}$ The strength of this movement was reflected in an informal referendum held across the Kurdistan region simultaneously with national elections of 2005; 98 per cent of voters expressed their preference for independent statehood. ${ }^{18}$ This brief historical background highlights the fortitude and proven endurance of the Kurdish nationalist movement, laying a foundation for the claim that the KRG's recent economic defiance of Baghdad is the natural trajectory of an ongoing aspiration, demonstrably sustained over time, to form an independent state of Kurdistan.

The KRG are gradually enforcing cultural and linguistic changes in Iraq's Kurdish society. This reinforces perceptions of seeking a more distinctive and separatist identity as the possible forerunner of independence. Schools in the Kurdish region now teach English and Turkish from the first grade. ${ }^{19}$ Arabic and Kurdish are the official languages of Iraq, as enshrined in the constitution. The KRG, however, enforced a change in the curriculum in Iraqi Kurdish schools in 2006 that saw the teaching of Arabic, which dominates the rest of the country, being delayed until the fourth grade. ${ }^{20}$ This was before the influx of foreign direct investment began to reshape the economic landscape of Kurdistan, countering arguments that claim the shift in language teaching is a response to the emerging Western currents flowing throughout the commercial boom. The decision to prioritise English and Turkish over Arabic suggests that the KRG has attempted to steer the cultural development of its region in a new direction, away from the crumbling control of centralist Iraqi institutions in Baghdad.

The debate surrounding the prospective independence of Kurdistan has become increasingly topical because of the region's significant economic growth. Before relations between Erbil and Baghdad deteriorated into the recent verbal and military hostilities, the KRG benefitted from a lucrative agreement in which the central government paid for the production costs of oil companies in Kurdistan. ${ }^{21}$ This was in addition to the 17 per cent of the annual Iraqi budget already being paid to the KRG, equating to 95 per cent of revenue. ${ }^{22}$ The Kurdistan region

17 Mahir A Aziz, The Kurds of Iraq: Ethnonationalism and National Identity in Iraqi Kurdistan (London: IB Tauris, 2011) 155. See also Denise Natali, The Kurds and the State: Evolving National Identity in Iraq, Turkey, and Iran (Syracuse University Press, 2005) xvii; Ofra Bengio, The Kurds of Iraq: Building a State Within a State (Boulder: Lynne Rienner, 2012) 9.

18 Peter Galbraith, The End of Iraq: How American Incompetence Created a War Without an End (New York: Simon \& Schuster) 171.

19 Karen Laub, '10 Years after Iraq's Liberation, Kurdistan Looks to the West', Kurd Net http://www.ekurd. net/mismas/articles/misc2013/3/state6913.htm (10 March 2013) accessed 9 April 2013.

20 Barham Omar, 'Kurds Hunger for English', Institute for War and Peace Reporting http://iwpr.net/reportnews/kurds-hunger-english (7 November 2007) accessed 9 April 2013.

21 Michael M Gunter, 'Iraqi Kurdistan's Two Contrasting Economic Images', International Journal of Contemporary Iraqi Studies 6:1 (2012) 90.

22 ibid. 
also chose to implement liberal investment laws that have attracted a wealth of foreign direct investment (FDI) ${ }^{23}$ The success of this approach was displayed in 2011 when FDI Magazine ranked Erbil as the fifth most promising destination in the Middle East for potential FDI. ${ }^{24}$ The combination of FDI and the lucrative oil management agreement with Baghdad fuelled unprecedented economic growth in the Kurdistan region, improving the Kurdish lifestyle significantly and setting it apart from the rest of Iraq, whose citizens can only envy relative luxuries such as near 24-hour electricity. The economic development of the Iraqi Kurds projects an image of prosperity, intensifying the cultural separation from the rest of Iraq. In this context, defying the central government by signing contracts that Baghdad declared unconstitutional can be perceived as a renewed and defiant push for independence.

Historically, Kurdish nationalism has proven to be steadfast in the face of continuous persecution. Culturally, schools have implemented curriculum changes that are steering Kurdish children's learning away from the Arab heritage of Iraq. Economically, the Kurdistan region has flourished, and the KRG's investment laws have helped to motivate and manoeuvre the Kurds to make rapid inroads in parts of their economy. Structurally, the Kurdistan Region of Iraq has a government that is considered legitimate by the people. It has entered into relations with other states and, apart from the border disputes in the south (which are not uncommon between states, especially in the Middle East), it exists within a defined territory. ${ }^{25}$ As Stansfield points out, these characteristics align precisely with the definition of a state in the 1933 Montevideo Convention on the Rights and Duties of States. ${ }^{26}$ Cumulatively, these historical, cultural, economic and structural features of the Kurdistan region portray a people and government in search of a state. In this context, the KRG signing contracts with IOCs could conceivably be an attempt to establish the income stream necessary to rejuvenate, promote and maintain a drive for independence. To accurately discern the KRG's motivations, however, a more comprehensive examination is needed.

\section{A Push for Independence or Disregard for the Iraqi Central Government?}

In order to objectively examine the strategic motives of the KRG, the wider domestic context must be taken into consideration. As the thriving oil sector

\footnotetext{
23 Kurdish Regional Government, Kurdistan: Invest in Democracy http://krg.org/uploads/documents/ Kurdistan_Investment_Guide_2011.pdf (April 2011) accessed 10 March 2013.

24 Iraq-Business News, 'Erbil Ranked Fifth for Foreign Direct Investment' http://www.iraq-businessnews. com/2011/03/16/erbil-ranked-5th-for-foreign-direct-investment/ (16 March 2011) accessed 10 March 2013.

25 Stansfield, 'The Unraveling of the Post-First World War State System?', 268.

26 ibid.
} 
of the Kurdish region has been a major driver of its economic prosperity, the dispute over the constitutional rights to manage the region's natural resources can be perceived as the predominant source of hostility between Erbil and Baghdad. In reality, it is the tip of the iceberg.

Although tensions have existed over natural resource management for some time, the downward spiral of relations began after the current Iraqi Prime Minister Nouri al-Maliki reneged on the conditions of power sharing that were reached in the Erbil Agreement in November 2010. ${ }^{27}$ The Kurds played a vital role in the negotiation of the Erbil Agreement, which secured the formation of the second Maliki government on the condition that the Prime Minister would cede control of key security ministries of the state. ${ }^{28}$ In response to Maliki's disloyal and manipulative politicking, Kurdish President Massoud Barzani and Iraqi President Jalal Talabani, the leader of the Patriotic Union of Kurdistan (PUK), attempted to orchestrate a vote of no confidence to remove Maliki from power. ${ }^{29}$ This failed attempt only fuelled Maliki's increasingly dictator-like leadership.

The disputes over territory, including the oil-rich city of Kirkuk, have been another propellant, or even accelerant, of this political blaze. In the months following the attempted vote of no confidence, the Kurdish forces known as the Peshmerga, and the Iraqi Security Forces (ISF) were deployed against each other in the province of Kirkuk. ${ }^{30}$ The political skirmish that grew out of Maliki's refusal to relinquish power, combined with the ongoing dispute over territory, shows that hostility between Erbil and Baghdad runs much deeper than disagreements over natural resource management. This suggests that the KRG's obstinate decision to continue signing IOC contracts could in fact be an antagonistic and aggressive move in a wider political battle, separate from any intent to establish an independent Kurdistan.

Displays of assertive economic policy by the Kurds are aggravating existing sectarian rifts in the delicate political landscape of Iraq. Since the withdrawal of US troops at the end of 2011, large segments of the Sunni Arab population in Iraq $^{31}$ have regarded the actions of Maliki as deliberately marginalising and

27 Ali Abel Sadah, 'Maliki Faces Tough Political Choices Ahead of Election', Al-Monitor http://www.almonitor.com/pulse/originals/2013/04/maliki-political-struggles-third-term.html (11 April 2013) accessed 12 April 2013.

28 Stansfield, 'The Unraveling of the Post-First World War State System?', 272.

29 Dina al-Shibeeb, 'Iraq: The Great Game of Unseating Premier', Al-Arabiya http://www.alarabiya.net/ articles/2012/06/05/218777.html (5 June 2012) accessed March 102013.

30 Stratfor, 'Turkey's Impact on Iraqi Relations' http://www.stratfor.com/geopolitical-diary/turkeysimpact-iraqi-relations (5 December 2012) accessed 12 April 2013.

31 Although Iraqi Kurds are predominantly Sunni, KRG cooperation with Sunni and Shi'a factions is driven by political expediency, not sectarian belief. This is unlikely to change given that the disputed territories to which the KRG lay claim are populated largely by Sunni Arabs, while the central government is predominantly 
subordinating the Sunni Arab minority. ${ }^{32}$ The latest wave of sectarian difficulty rose in 2011 when Maliki issued an arrest warrant for the Sunni Vice-President Tariq al-Hashemi. ${ }^{33}$ In contrast with the views of Anthony Blinken, who in 2012 described Iraq's 'progress towards a more normal political existence' as being 'remarkable', ${ }^{34}$ sectarian violence has since worsened. In late 2012 and early 2013, demonstrations erupted across Iraq in Fallujah, Ramadi, Tikrit and Mosul. ${ }^{35}$ Many of these protests called for the Iraqi government to step down and for the police force to withdraw, accusing Maliki of being a dictator. ${ }^{36} \mathrm{~A}$ dramatic increase in sectarian-motivated bombings has since ensued. ${ }^{37}$ The last time Maliki faced such growing unrest throughout the provinces of Iraq was during the height of the civil conflict in 2006-07, when he was allied with the KRG and also had the support of the US troops. ${ }^{38}$ US troops have since departed and relations between Erbil and Baghdad have soured dramatically. By signing contracts with IOCs, the KRG is defying Maliki's predominantly Shi'a government, strengthening the claims of much of the Sunni Arab population that Maliki is an illegitimate leader.

The KRG's management of its natural resources is fuelling more than just sectarian violence; it is acting as an achievable template and encouraging wider decentralisation of Iraq's energy sector and demands for greater regional autonomy. Kurdistan, Iraq's only federal region, has become the safest and arguably most prosperous part of Iraq. Other provinces perceive this prosperity to be a result of the KRG's increasingly independent natural resource sector and are attempting to gain a similar level of autonomy. Richard Wadsworth, the CEO of Canadian firm Sonoro Energy, recently claimed to have signed an asphalt licence agreement with the province of Salahuddin. ${ }^{39}$ Similarly, a preliminary prospectus for Canadian company Oryx Petroleum states that an agreement with the province of Wasit has been signed. ${ }^{40}$ The heterogeneous Ninewa province,

Shi'a. See International Crisis Group, 'Make or Break: Iraq's Sunni's and the State', Middle East Report 144 http://www.crisisgroup.org/en/regions/middle-east-north-africa/iraq-iran-gulf/iraq/144-make-or-break-iraqs-sunnis-and-the-state.aspx (14 August 2013) accessed 28 October 2013.

32 Gareth Stansfield, 'A Year of Endemic Instability in Iraq', Royal United Services Institute http://www.rusi. org/analysis/commentary/ref:C50E592AAAEC92/\#.UXZ85ZimBto (3 January 2013) accessed 12 April 2013.

33 Ahmed Rasheed, 'Iraq says Turkey Rejects Kurd export pipelines', Reuters http://www.reuters.com/ article/2013/02/25/us-iraq-turkey-oil-idUSBRE91O0L520130225 (25 February 2013) accessed 10 March 2013.

34 Anthony Blinken, 'Is Iraq on Track?: Democracy and Disorder in Baghdad', Foreign Affairs 91:4 (July/ August 2012) 153.

35 Stansfield, 'The Unraveling of the Post-First World War State System?, 272.

36 Burak Bilgehan Özpek, 'Democracy or Partition: Future Scenarios for the Kurds of Iraq', Insight Turkey 14:3 (2012) 128.

37 Stratfor, 'An Increasingly Unstable Iraq' http://www.stratfor.com/video/increasingly-unstable-iraq (23 January 2013) accessed 10 March 2013.

38 Stansfield, 'Year of Endemic Instability'.

39 John Lee, 'Interview with Richard Wadsworth', Iraq-Business News http://www.iraq-businessnews. com/2012/11/27/video-sonoro-energy-targets-northern-iraq/ (27 November 2012) accessed 10 March 2013. 40 Ben Lando, 'Oil Autonomy Spreading to Iraq's Provinces', Iraq Oil Report http://www.iraqoilreport.com/ politics/oil-policy/oil-autonomy-spreading-to-iraqs-provinces-10635/ (19 April 2013) accessed 20 April 2013. 
which is made up of Christians, Sunni Arabs and Kurds, is experiencing a similar phenomenon, with the local Christian population calling for its own autonomous area within Ninewa. ${ }^{41}$ This is the same disputed territory that includes the Bashiqa oil exploration block issued to ExxonMobil by the KRG. ${ }^{42}$

These expressions of provincial independence coincide with burgeoning demands by Sunni Arabs for their own regional federalism. ${ }^{43}$ The perceived autonomy of the Kurdistan region, which the KRG flaunts by signing contracts with IOCs, is fuelling demands for similar levels of independence throughout the rest of the country and encouraging other provinces to manage Iraq's local energy resources for their own regional benefits. These destabilising factors are chipping away at what hopes remain, and what international agencies and organisations might wish, for Iraqi unity.

\section{A Regional Relationship of Convenience}

An increasingly intensified collaboration between the Turkish Government and the KRG appears to be integral to furthering the economic autonomy of the Iraqi Kurds. The foundations of this partnership have been laid over the past five years as Turkish businesses have invested heavily in the growing economy of Iraqi Kurdistan. ${ }^{44}$ This has evolved into a thriving trade relationship, with US $\$ 12$ billion in KRG-Turkey trade taking place in 2011. ${ }^{45}$ In 2010 Turkish trade with the KRG was greater than Turkish trade with Syria, Lebanon and Jordan combined. ${ }^{46}$ This relationship recently became central to the KRG's economic future, as Genel Energy has begun building a pipeline between the Taq Taq oilfield and an existing Iraq-Turkey pipeline. ${ }^{47}$ Although an official agreement between Erbil and Ankara is yet to be confirmed, Turkish Prime Minister Recep Tayyip Erdogan openly stated in March 2013 that he perceives any such agreement to be within the limits of the Iraqi constitution. ${ }^{48}$ This indicates Erdogan is resolved to persist with such an agreement, reinforced by his recent proposal for Turkey to create an escrow account through which it

\footnotetext{
41 Denise Natali, 'The Politics of Kurdish Crude', Middle East Policy 19:1 (Spring 2012) 112.

42 ibid.

43 ibid.

44 Shwan Zulal, 'Survival Strategies and Diplomatic Tools: The Kurdistan Region's Foreign Policy Outlook', Insight Turkey 14:3 (2012) 143.

45 Robin Mills, 'Northern Iraq's Oil Chessboard: Energy, Politics and Power', Insight Turkey 15:1 (2013) 59.

46 ibid.

47 Orhan Coskun, 'Iraqi Kurdistan Poised to Pipe Oil to World via Turkey', Reuters http://www.reuters. com/article/2013/04/17/iraq-kurdistan-oil-idUSL5NOD310920130417 (17 April 2013) accessed 19 April 2013. 48 Mustafa Akyol, 'Erdogan's Kurdish Policies Break from Kurdish Past', Al-Monitor http://www.al-monitor. com/pulse/originals/2013/03/erdogan-kurdish-policy-shift-ocalan-speech.html (22 March 2013) accessed 19 April 2013.
} 
could manage the distribution of the oil revenues for both Baghdad and Erbil. ${ }^{49}$ On the surface, the forging of closer relations between Erbil and Ankara appears to be a possible gateway for the level of economic and regional autonomy that could support an independent Kurdish state.

A closer examination of the motivations underlying improved relations between the KRG and Turkey is required before it can be considered an economic platform from which an independent Kurdish state could potentially be launched. A major contributing factor to the newfound friendship between Turkey and the Iraqi Kurds is the conflict in Syria. In the current civil war, two main Syrian Kurdish opposition parties have come to prominence in the north of the country. The Democratic Union Party (PYD) is a Syrian Kurdish branch of the Kurdistan Workers' Party (PKK), the rebel Kurdish group, widely considered to be a terrorist organisation, which is now based out of Iraqi Kurdistan and fights for Kurdish recognition within Turkey. The other main organisation is the Kurdish National Council (KNC), which is comprised of 12 smaller Kurdish parties that combined to form the KNC under the guidance of KRG President Barzani in late 2011. ${ }^{50}$

Barzani has used his leverage over the KNC to negotiate an agreement between it and the PYD that aimed to achieve joint leadership within Syrian cities previously dominated by the PYD. ${ }^{51}$ Ankara considers the PYD to be a duplicate of the PKK, which fought against Turkey for Turk-Kurdish autonomy in a bloody conflict that started in $1990 .{ }^{52}$ Hence, Ankara is cautious of the rising power of the PYD in Syria, perceiving it to be a potential springboard for the PKK. ${ }^{53}$ Barzani's negotiations were, therefore, received warmly by Ankara as it attempted to dilute the power of the PYD within Syria. ${ }^{54}$ This suggests that by improving relations with the KRG and supporting its interpretation of the Iraqi constitution, Ankara is strategically positioning itself to gain greater influence over the KRG in the hope of minimising the perceived threat posed by Syria's PYD. Ankara's foreign policy objectives run deeper still.

Turkey's alliance with the KRG will also help to check any aspirations that the KRG may have of establishing a wider Kurdistan. Superficially, Barzani's attempt to foster power sharing in his neighbouring region is unsurprising. KDP-PUK

\footnotetext{
49 Denise Natali, 'Can Turkey Leverage Kurdish Crude?', Al-Monitor http://www.al-monitor.com/pulse/ originals/2013/04/turkey-kurdish-oil-crude-baghdad-leverage-energy-policy.html?utm_source $=\& u t m \_$ medium=email\&utm_campaign=6850 (8 April 2013) accessed 19 April 2013.

50 Stansfield, 'The Unraveling of the Post-First World War State System?, 280.

51 Ben Gittleson, 'Syria's Kurds look to Iraqi Minority for Support', New York Times http://www.nytimes. com/2013/01/31/world/middleeast/31iht-m31-kurds.html?_r=0 (31 January 2103) accessed 10 March 2013.

52 Kemal Kirişci, 'Turkey's Kurdish Challenge', in The Kurdish Policy Imperative, eds Robert Lowe and Gareth Stansfield (London: Royal Institute of International Affairs, 2010) 59.

53 International Crisis Group, 'Syria's Kurds: A Struggle Within a Struggle', Middle East Report 136 (22 January 2013) accessed 10 April 2013.

54 Stansfield, 'The Unraveling of the Post-First World War State System?, 280.
} 
infighting in the 1990s restrained the Iraqi Kurdish nationalist movement. ${ }^{55}$ Barzani's facilitation of a compromise between the PYD and KNC can, therefore, be seen as the President spreading the wisdom from his hard-learned lesson. The ethnic Kurdish homeland, however, extends across southern Turkey, northern Iraq, eastern Iran and north-western Syria. ${ }^{56}$ Turkey has violently oppressed the PKK for over two decades, sending a clear message about its stance on the prospect of Kurdish autonomy outside of Iraq. Although Ankara and the PKK have outlined a peace arrangement, its implementation has been problematic, troubled by underlying distrust. Similarly, in relation to Barzani's negotiations with the Syrian Kurdish factions, not enough time has passed to quell Turkish suspicions that the president of the KRG may seek to rule over a wider Kurdish population that extends beyond the borders of Iraq. ${ }^{57}$ This same bordering ally, which may be perceived as a potentially willing partner in furthering the economic autonomy necessary to establish an independent Kurdistan, has a long and bloody history of opposing any transgressions or incursions of its own claimed territories. This has been the underlying motivation for Turkey's historical and ongoing opposition to an independent Kurdish state, a steadfast position that reveals the political expedience driving Turkey's recent cooperation with the KRG.

\section{The Realities of Independence}

Economic dependence on Baghdad firmly limits the ability of the KRG to establish its independence. The central government currently supplies Erbil with 17 per cent of the federal Iraqi budget, equating to US\$10 billion annually, or about 95 per cent of its revenue. ${ }^{58}$ This income stream has been crucial to the socioeconomic development of the region. The KRG's attempts to increase its economic autonomy portray a hope for economic independence in the future. The chief executive of Genel Energy, the IOC pumping oil from the Kurdish fields of Taq Taq and Tawke, claims that the production capacity of the Kurdish region by the end of 2013 could reach close to one million barrels per day. ${ }^{59}$ This would be a sizeable increase of the current capacity of 400,000 barrels per day, a figure that is yet to be achieved because of the continuing dispute with Baghdad.

\footnotetext{
55 Gareth Stansfield, Iraqi Kurdistan, Political Development and Emergent Democracy, (New York: RoutledgeCurzon, 2003) 97-100.

56 McDowall, A Modern History of the Kurds, 1.

57 Stansfield, 'The Unraveling of the Post-First World War State System?, 280.

58 Denise Natali, 'Who Will Pay IOCs in Iraqi Kurdistan?', Al-Monitor http://www.al-monitor.com/pulse/ originals/2013/02/iraq-turkey-pipeline-reduce-tensions-between-baghdad-ankara.html (20 February 2013) accessed 10 March 2013.

59 Peg Mackey, 'Genel's Tony Hayward says Iraq's Kurdistan Oil Row Too Big to Last', Reuters http:// in.reuters.com/article/2012/09/07/us-genel-kurdistan-idINBRE8860K620120907 (7 September 2013) accessed 10 March 2010.
} 
Although the prospect of considerable growth in Kurdistan's oil sector appears promising, the IOCs that it is assumed will be extracting the oil are the same IOCs that are owed vast sums of money. ${ }^{60}$ Under the agreement described earlier, the central government is responsible for paying these companies. Baghdad, however, in deeming these contracts unconstitutional, has largely refused to pay. ${ }^{61}$ This casts doubt over any figures predicting future increases in Kurdish oil exports, as such an increase is reliant on the continued commitment of IOCs that are currently owed an accumulative total of US $\$ 4$ billion. ${ }^{62}$ With relations between Erbil and Baghdad disintegrating, this dispute is unlikely to be settled, leaving the KRG reliant on its portion of the national Iraqi budget, thereby limiting any strategy to seek independence. ${ }^{63}$

The city of Kirkuk and the surrounding disputed territories are integral to the economic independence needed to fund an independent state. One of the controversial elements of the KRG's contracts with IOCs relates to some of these locations. For instance, three of the six blocks contracted to the American firm ExxonMobil are located in disputed border areas in the provinces of Kirkuk and Ninewa. ${ }^{64}$ Although the central government has refused to pay the production costs of these ventures, it has not tried to physically intervene or use military force to prevent exploration going ahead. The armed hostilities that took place towards the end of last year between the Peshmerga and the ISF, however, suggest that if the KRG tried to secede, it could only include the disputed territories in its borders, if it was able to take them by force. Although the scale of the conflict is difficult to predict, Baghdad's military power is mightier than that of Erbil, as it is equipped with US-supplied F16s and Ml tanks. ${ }^{65}$

Furthermore, Turkey may be fostering closer economic ties with the KRG, but it has also made clear that it does not support the Kurdish claims for the disputed city of Kirkuk. ${ }^{66}$ If the oil in Kirkuk and the surrounding disputed territories is unavailable to the KRG, then it is predicted that it could not export enough oil to replace its current share of the Iraqi national budget. ${ }^{67}$ The centrality of the disputed territories to the economic autonomy of the KRG

\footnotetext{
60 Petroleum Economist, 'Iraq's Fractious Politics Weigh on Oil Sector' http://www.petroleum-economist.com/ Article/3148564/Search/Iraqs-fractious-politics-weigh-on-oil-sector.html (30 January 2013) 10 March 2013.

61 ibid.

62 Natali, 'Who Will Pay IOCs in Iraqi Kurdistan?'.

63 Ranj Alaaldin, 'Now is Not the Time for an Independent Kurdistan', Asharq Al-Awsat Online http:// www.aawsat.net/2013/04/article55298103 (8 April 2013) accessed 9 April.

64 Natali, 'The Politics of Kurdish Crude', 112.

65 Ben Lando, 'Interview with General James Jones', Iraq Oil Report http://www.iraqoilreport.com/ business/companies/qa-gen-james-jones-9571/ (26 December 2012) accessed 19 April 2012; Reuters, 'Iraq Signs Contract for 18 F-16 Fighter Jets' http://www.reuters.com/article/2012/10/18/us-iraq-military-jetsidUSBRE89H14B20121018 (18 October 2012) accessed 10 April 2013.

66 Natali, 'The Politics of Kurdish Crude', 113.

67 Alaaldin, 'Now is Not the Time for an Independent Kurdistan'.
} 
is a definitive barrier blocking any alleged march to freedom, persuasively challenging the notion that signing contracts with IOCs is a strategic ploy directly aimed at achieving independence.

International relations with Iraqi Kurdistan have been rapidly increasing, but this does not translate into tangible or practicable international support for an independent Kurdistan. As previously stated, 'the capacity to enter into relations with other states' is a key characteristic of the 1930 Montevideo convention. ${ }^{68}$ The KRG has a proven capacity for inter-state relations, but there remains a strong and formidable opponent of Kurdish secession: the United States. Although the United States worked closely with the Kurds during the invasion, occupation and reconstruction of the country, it has maintained an uncompromising stance on pursuing its 'One Iraq' policy. ${ }^{69}$ When hostilities surged in the disputed territories during late 2012 in what threatened to be the first military engagement between the Peshmerga and ISF in the postSaddam era, Washington contacted Barzani directly to make clear the strong US opposition to the prospect of secession. ${ }^{70}$

The increasing regional division between Sunni and Shi'a dominated states has reinforced Washington's view. Given Ankara's souring relations with Baghdad and Tehran, Washington is concerned that an independent Kurdistan, in its current close relations with Turkey, could drive Baghdad even further into the embrace of Tehran, strengthening Iran's 'arc of influence'. ${ }^{71}$ The staunch US resistance to Kurdish independence will influence its allies and, most likely, prevent them from supporting secession within Iraq, potentially undermining the recognised legitimacy of an independent Kurdistan.

To contend that the KRG's signing of contracts with IOCs is geared towards obtaining independence is to assume that a clear strategy has been devised in Erbil. In reality, disagreement between the major parties and political players in the domestic politics of Iraqi Kurdistan raises serious doubts as to whether a clear or a unified direction exists. Since the official agreement between the KDP and PUK in 2007, both parties have put their differences behind them and cooperate for the stability of their region. Differences of opinion still arise however.

During the political row with Baghdad over budget allocations earlier this year, the PUK and KDP disagreed over how best to react to the situation. After boycotting the vote to approve the national budget, which was then passed in their absence, the possibility of withdrawing from the parliament in Baghdad

68 Stansfield, “The Unraveling of the Post-First World War State System?, 268.

69 Denise Natali, The Kurdish Quasi-state (New York: Syracuse, 2010) 133.

70 Alaaldin, 'Now is Not the Time for an Independent Kurdistan'.

71 Stratfor, 'Iran's Arc of Influence in Jeopardy' http://www.stratfor.com/analysis/irans-arc-influencejeopardy (3 August 2012) accessed 10 March 2013. 
was considered by members of the KDP. ${ }^{72}$ The PUK quickly rejected this call, claiming it would cause greater difficulties for the KRG. ${ }^{73}$ Withdrawing ministers from the Baghdad parliament is not as extreme as claiming independence. The difference of opinions between the PUK and KDP on how best to manage relations with Baghdad regarding the fallout over the national budget, however, suggests that the KRG is lacking a coherent or consistent strategic plan.

\section{Conclusion}

Striving for greater economic autonomy by continuing to sign contracts with IOCs has incited a wave of sanguine speculation about the possible or planned future of the Kurds within Iraq. However great the number of journalists and academics to jump on this bandwagon of optimistic predictions, and whatever the extent of the speculation, the fact remains that crystal-ball gazing and analysis of covert intentions is a perilous art. The reality of Turkish foreign policy, the continued economic dependence on Baghdad, the strong opposition of Washington and the warfare that would likely ensue if the Kurds tried to claim Kirkuk, together form a formidable obstacle to Kurdish statehood being realised in the near future. Furthermore, the disunity and infighting within the Kurdish camp casts doubt on the prospect of a grand plan paving the road to the establishment of a self-determining state.

Independence may be currently out of reach, but the limits of Kurdish autonomy are yet to be clearly demarcated, and notional or conceptual boundaries can be pushed by commercial opportunities. The KRG's contracts with IOCs are a strategic manoeuvre designed to maximise the economic autonomy of the Kurdistan region. Exacerbating domestic sectarian rifts, reinforcing the regional Sunni-Shi'a divide, and encouraging attempts at secession by other oilproducing provinces are ultimately destabilising results of this ambitious, but ultimately, self-interested gambit, which viewed through the lens of powerful players outside the region, can well be considered dangerous and threatening to any remaining hopes for a secure and unified Iraq. While dreams of independence remain constrained, the message from Erbil is loud and clear: even without an independent state, Iraqi Kurdistan and its resources belong to the Kurds.

72 Aseel Kami, 'Iraq Passes Budget Despite Kurdish Boycott', Reuters http://www.reuters.com/ article/2013/03/07/iraq-budget-parliament-idUSL6NOBZHIW20130307 (7 March 2013) accessed 10 March 2013. 73 National Iraqi News Agency, 'Kurdistan Rules out Withdrawal from Iraqi Government, Disagreement between KDP and PUK', Kurd Net http://ekurd.net/mismas/articles/misc2013/3/state6914.htm (10 March 2013) accessed 10 March 2013. 
The ANU Undergraduate Research Journal

\section{Bibliography}

Akyol, Mustafa. "Erdogan's Kurdish Policies Break from Kurdish Past". Al-Monitor http://www.al-monitor.com/pulse/originals/2013/03/erdogan-kurdish-policyshift-ocalan-speech.html (22 March 2013) accessed 19 April 2013.

Alaaldin, Ranj. 'Now is Not the Time for an Independent Kurdistan'. Asharq Al-Awsat http://www.aawsat.net/2013/04/article55298103 (8 April 2013) accessed 9 April 2013.

al-Shibeeb, Dina. 'Iraq: The Great Game of Unseating Premier'. Al-Arabiya http://www.alarabiya.net/articles/2012/06/05/218777.html (5 June 2012) accessed March 102013.

Anderson, Liam. 'Internationalizing Iraq's Constitutional Dilemma'. In The Kurdish Policy Imperative. Eds Lowe, Robert and Stansfield, Gareth (London: Royal Institute of International Affairs, 2010).

Aziz, Mahir A. The Kurds of Iraq: Ethnonationalism and National Identity in Iraqi Kurdistan (London: IB Tauris, 2011).

Bengio, Ofra. The Kurds of Iraq: Building a State Within a State (Boulder: Lynne Rienner, 2012).

Blanche, Ed. 'Kurds: Attaining the Impossible Dream?'. The Middle East 440:1 (February 2013) 13-16.

Blinken, Anthony. 'Is Iraq on Track?: Democracy and Disorder in Baghdad'. Foreign Affairs 91:4 (July/August 2012) 152-54.

Cameron, Peter D. 'Contracts and Constitutions: The Kurdish Factor in the Development of Oil in Iraq'. International Journal of Contemporary Iraqi Studies 5:1 (2011) 81-99.

Coskun, Orhan. 'Iraqi Kurdistan Poised to Pipe Oil to World via Turkey'. Reuters http://www.reuters.com/article/2013/04/17/iraq-kurdistan-oilidUSL5N0D310920130417 (17 April 2013) accessed 19 April 2013.

Galbraith, Peter. The End of Iraq: How American Incompetence Created a War Without an End (New York: Simon \& Schuster).

Gittleson, Ben. 'Syria's Kurds look to Iraqi Minority for Support'. New York Times http://www.nytimes.com/2013/01/31/world/middleeast/31iht-m31kurds.html?_r=0 (31 January 2103) accessed 10 March 2013.

Gunter, Michael M. 'Iraqi Kurdistan's Two Contrasting Economic Images'. International Journal of Contemporary Iraqi Studies 6:1 (2012) 89-95. 
International Crisis Group. 'Syria's Kurds: A Struggle Within a Struggle'. Middle East Report 136 http://www.crisisgroup.org/en/regions/middle-east-northafrica/egypt-syria-lebanon/syria/136-syrias-kurds-a-struggle-within-astruggle.aspx (22 January 2013) accessed 10 April 2013.

- 'Make or Break: Iraq's Sunni's and the State'. Middle East Report 144 http://www.crisisgroup.org/en/regions/middle-east-north-africa/iraq-irangulf/iraq/144-make-or-break-iraq-s-sunnis-and-the-state.aspx (14 August 2013) accessed 28 October 2013.

Iraq-Business News. 'Erbil Ranked Fifth for Foreign Direct Investment'. http://www.iraq-businessnews.com/2011/03/16/erbil-ranked-5thfor-foreign-direct-investment/ (16 March 2011) accessed 10 March 2013.

Jwaideh, Wadie. The Kurdish National Movement: Its Origins and Development (Syracuse: Syracuse University Press, 2006).

Kami, Aseel. 'Iraq Passes Budget Despite Kurdish Boycott'. Reuters http:// www.reuters.com/article/2013/03/07/iraq-budget-parliament-idUSL6N0BZ HIW20130307 (7 March 2013) accessed 10 March 2013.

Kirişci, Kemal. 'Turkey's Kurdish Challenge'. In The Kurdish Policy Imperative. Eds Lowe, Robert and Stansfield, Gareth (London: Royal Institute of International Affairs, 2010).

Kurdish Regional Government. Kurdistan: Invest in Democracy http://krg.org/ uploads/documents/Kurdistan_Investment_Guide_2011.pdf (April 2011) accessed 10 March 2013.

Lando, Ben. 'Interview with General James Jones'. Iraq Oil Report http://www. iraqoilreport.com/business/companies/qa-gen-james-jones-9571/ (26 December 2012) accessed 19 April 2012.

. 'Oil Autonomy Spreading to Iraq's Provinces'. Iraq Oil Report http:// www.iraqoilreport.com/politics/oil-policy/oil-autonomy-spreadingto-iraqs-provinces-10635/ (19 April 2013) accessed 20 April 2013.

Laub, Karen. '10 Years after Iraq's Liberation, Kurdistan Looks to the West'. Kurd Net http://www.ekurd.net/mismas/articles/misc2013/3/state6913.htm (10 March 2013) accessed 9 April 2013.

Lee, John. 'Interview with Richard Wadsworth'. Iraq-Business News http:// www.iraq-businessnews.com/2012/11/27/video-sonoro-energy-targetsnorthern-iraq/ (27 November 2012) accessed 10 March 2013. 
The ANU Undergraduate Research Journal

Mackey, Peg. 'Genel's Tony Hayward says Iraq's Kurdistan Oil Row Too Big to Last'. Reuters http://in.reuters.com/article/2012/09/07/us-genel-kurdistanidINBRE8860K620120907 (7 September 2013) accessed 10 March 2010.

Malazada, Ibrahim. 'Now is the Time for an Independent Kurdistan'. Asharq Al-Awsat http://www.aawsat.net/2013/04/article55298106 (8 April 2013) accessed 9 April 2013.

McDowall, David. A Modern History of the Kurds (New York: St Martin's Press, 2004).

Mills, Robin. 'Northern Iraq's Oil Chessboard: Energy, Politics and Power'. Insight Turkey 15:1 (2013) 51-62.

Natali, Denise. The Kurdish Quasi-state (Syracuse: Syracuse, 2010).

Natali, Denise. The Kurds and the State: Evolving National Identity in Iraq, Turkey, and Iran (Syracuse University Press, 2005).

. 'The Spoils of Peace in Iraqi Kurdistan'. Third World Quarterly 28:6 (August 2007) 1111-129.

. 'The Politics of Kurdish Crude'. Middle East Policy 19:1 (Spring 2012) 110-18.

'Who Will Pay IOCs in Iraqi Kurdistan?'. Al-Monitor http://www.almonitor.com/pulse/originals/2013/02/iraq-turkey-pipeline-reduce-tensionsbetween-baghdad-ankara.html (20 February 2013) accessed 10 March 2013.

'Can Turkey Leverage Kurdish Crude?'. Al-Monitor http://www.almonitor.com/pulse/originals/2013/04/turkey-kurdish-oil-crude-baghdadleverage-energy-policy.html?utm_source=\&utm_medium=email\&utm_ campaign=6850 (8 April 2013) accessed 19 April 2013.

National Iraqi News Agency. 'Kurdistan Rules out Withdrawal from Iraqi Government, Disagreement between KDP and PUK'. Kurd Net http://ekurd. net/mismas/articles/misc2013/3/state6914.htm (10 March 2013) accessed 10 March 2013.

Omar, Barham. 'Kurds Hunger for English'. Institute for War and Peace Reporting Online http://iwpr.net/report-news/kurds-hunger-english (7 November 2007) accessed 9 April 2013.

Özpek, Burak Bilgehan. 'Democracy or Partition: Future Scenarios for the Kurds of Iraq'. Insight Turkey 14:3 (2012) 127-40. 
Petroleum Economist. "Iraq's Fractious Politics Weigh on Oil Sector". Petroleum Economist http://www.petroleum-economist.com/Article/3148564/Search/ Iraqs-fractious-politics-weigh-on-oil-sector.html (30 January 2013) 10 March 2013.

Rasheed, Ahmed. 'Iraq says Turkey Rejects Kurd Export Pipelines'. Reuters http://www.reuters.com/article/2013/02/25/us-iraq-turkey-oilidUSBRE91O0L520130225 (25 February 2013) accessed 10 March 2013.

Reuters. 'Iraq Signs Contract for 18 F-16 Fighter Jets' http://www.reuters. com/article/2012/10/18/us-iraq-military-jets-idUSBRE89H14B20121018 (18 October 2012) accessed 10 April 2013.

Sadah, Ali Abel. "Maliki Faces Tough Political Choices Ahead of Election". AlMonitor http://www.al-monitor.com/pulse/originals/2013/04/maliki-politicalstruggles-third-term.html (11 April 2013) accessed 12 April 2013.

Stansfield, Gareth. Iraqi Kurdistan, Political development and emergent democracy (New York: RoutledgeCurzon, 2003).

. Iraq (Cambridge: Polity, 2007).

. 'A Year of Endemic Instability in Iraq'. Royal United Services Institute http://www.rusi.org/analysis/commentary/ref:C50E592AAAEC92/\#. UXZ85ZimBto (3 January 2013) accessed 12 April 2013.

. 'The Unraveling of the Post-First World War State System? The Kurdistan Region of Iraq and the Transformation of the Middle East'. International Affairs 89:2 (2013) 259-82.

Stratfor. 'Iran's Arc of Influence in Jeopardy'. http://www.stratfor.com/analysis/ irans-arc-influence-jeopardy (3 August 2012) accessed 10 March 2013

. 'Turkey's Impact on Iraqi Relations'. http://www.stratfor.com/ geopolitical-diary/turkeys-impact-iraqi-relations (5 December 2012) accessed 12 April 2013.

. 'An Increasingly Unstable Iraq'. http://www.stratfor.com/video/ increasingly-unstable-iraq (23 January 2013) accessed 10 March 2013.

The Economist. 'Northern Iraq: Peace, Harmony and Oil'. http://www.economist. com/news/middle-east-and-africa/21576394-despite-assertions-contraryiraqs-kurds-are-inching-towards-outright (20 April 2013) access 21 April 2013.

Zulal, Shwan. 'Survival Strategies and Diplomatic Tools: The Kurdistan Region's Foreign Policy Outlook'. Insight Turkey 14:3 (2012) 141-58. 
This text taken from The ANU Undergraduate Research Journal Volume Five 2013, published 2014 by ANU Press, The Australian National University, Canberra, Australia. 